\title{
Scriptural Authority and Scriptural Argumentation in 1 Clement
}

\author{
Kujanpää, Katja
}

2020-01

Kujanpää , K 2020 , ' Scriptural Authority and Scriptural Argumentation in 1 Clement ' , New

Testament Studies, vol. 66 , no. 1 , pp. 125-143 . https://doi.org/10.1017/S0028688519000353

http://hdl.handle.net/10138/314782

https://doi.org/10.1017/S0028688519000353

acceptedVersion

Downloaded from Helda, University of Helsinki institutional repository.

This is an electronic reprint of the original article.

This reprint may differ from the original in pagination and typographic detail.

Please cite the original version. 
Katja Kujanpää

Faculty of Theology

P.O. Box 4

FIN-00014 University of Helsinki

Finland

katja.kujanpaa@helsinki.fi

\title{
Scriptural Authority and Scriptural Argumentation in 1 Clement
}

\begin{abstract}
Drawing from recent insights concerning textual authority, this article examines how the authoritativeness of the Jewish scriptures is manifested in 1 Clement. The article argues that the relationship between the letter and the writings it uses in its argumentation should be seen as a twoway process of mutual authorisation. Moreover, the article illuminates the interrelatedness of textual authority, scriptural argumentation and the legitimation of leadership and power. Thus, the analysis both contributes to the ongoing scholarly discussions on scriptural authority and highlights the role of scriptural argumentation in the identity-building of early Christians.
\end{abstract}

Keywords: authority, scriptural argumentation, 1 Clement, the Septuagint, Apostolic Fathers, early Christianity

\section{Introduction}

Much of the rhetorical force of the letter known as 1 Clement is derived from the use of the Jewish scriptures, which are constantly cited, paraphrased or otherwise referred to in the letter. ${ }^{1}$ The purpose of this article is 1) to examine how the authoritativeness of these writings is manifested in the letter, 2) to illustrate the process and dynamics of mutual authorisation between the letter and the writings it quotes, and 3) to highlight connections between scriptural argumentation and the legitimation of power structures.

In recent years, the concept of scriptural authority has received much attention among biblical scholars. What demonstrates that a text has authority for a certain community? How can texts acquire authority? Can writers, editors or other transmitters enhance or promote the authoritativeness of their text? Scholars working with the Dead Sea scrolls have particularly contributed to the discussion, for the non-canonical writings (to use the anachronism) readily evoke questions related to their authoritativeness, status, and their aim in relation to earlier writings. Questions concerning authority are integral to discussing the formation of a canon, yet the authoritativeness of texts is a larger category than their canonicity. Authority has been shown to be a multifaceted phenomenon that manifests itself in different ways at different stages of composing,

\footnotetext{
${ }^{1}$ I would like to offer my warm thanks to the Oxford Centre for Hebrew and Jewish Studies for its hospitality during my time as a visiting scholar when I worked on this article.
} 
transmitting, and interpreting writings. ${ }^{2}$ In this article, I will draw from recent insights concerning the authority of texts and apply them to illuminate the scriptural argumentation of 1 Clement.

1 Clement is a genuine letter from Rome to Corinth, ${ }^{3}$ traditionally dated to the very end of the first century, ${ }^{4}$ yet more recent research tends to allow a broader time frame. ${ }^{5}$ Its objectives relate to a specific situation in Corinth, a dispute concerning leadership and governance of the congregation. Some of the established leaders, who are called (apparently interchangeably) bishops or presbyters, have been 'removed from their ministry' (44.4-6; see also 3.3; 47.6). Using deliberative rhetoric, the letter from Rome is a call for peace and concord, highlighting the virtue of humility and the importance of order and submission. ${ }^{6}$ All this is argued for on the basis of scriptural narratives and lengthy quotations, the authoritativeness of which appears to be a self-evident starting point. The letter is a journey through the Jewish scriptures: it takes up characters, longer or shorter episodes of narratives, motifs, and terminology. While the letter itself uses the first person plural of its senders, the consistent style and language point to one author whom I will for the sake of simplicity call Clement. $^{7}$

In the following, I will first illuminate the phenomenon of scriptural authority through the concept of mutual authorisation. This concept helps to highlight the two-way dynamics in the use of authoritative texts. Second, I will examine how the authoritativeness of writings is articulated and implied in the letter itself. The third section of the article discusses the relationship between the authority of scriptural texts and the immutability of their wording. Then I will examine in more detail one quotation that shows how scriptural authority can be used to authorise power structures. In the final section before my conclusions, I will turn to the authority of 1 Clement itself.

\footnotetext{
${ }^{2}$ Phenomena related to authority have also intrigued scholars working with non-biblical ancient writings; cf. the case studies in the recent edited volumes On Good Authority: Tradition, Compilation and the Construction of Authority in Literature from Antiquity to the Renaissance (ed. R. Ceulemans and P. de Leemans (Lectio 3; Turnhout, Belgium: Brepols, 2015); Shaping Authority: How Did a Person Become an Authority in Antiquity, the Middle Ages and the Renaissance? (ed. S. Boodts, J. Leemans and B. Meijns; Lectio 4; Turnhout: Brepols, 2016).

${ }^{3}$ Pace C. K. Rothschild (New Essays on the Apostolic Fathers (WUNT 375; Tübingen: Mohr Siebeck, 2017)), who argues for an allegorical and theological interpretation of Rome and Corinth: 'Rome might connote those whom the author associated with proto-orthodoxy in Rome' and Corinth 'those whom the author associated with the wayward behavior Paul addresses in his first letter to the Corinthians' (p. 63). According to Rothschild, the letter is based on a 'historical fiction' and was 'neither written from a church in Rome not intended for (let alone delivered to) a Church in Corinth' (p. 66). However, the arguments Rothschild raises against viewing 1 Clement as a true letter from Rome to Corinth are weak. She mentions 'the lack of historical evidence' concerning churches in Corinth and Rome, and makes much of the fact that the epistolary elements were not accepted as the title of the letter. Furthermore, I am far from convinced that 'Corinth' would function as a self-evident symbol for wayward behaviour and 'Rome' for 'protoorthodoxy' and 'Paul's legacy'.

${ }^{4}$ See e.g. A. Jaubert, Clément de Rome: Épître aux Corinthiens: Introduction, Texte, Traduction, Notes et Index (Sources Chrétiennes 167; Paris: Éditions du Cerf, 2000²) 20; A. Lindemann, Die Clemensbriefe (Handbuch zum Neuen Testament 17; Tübingen: Mohr Siebeck, 1992) 12; H. E. Lona, Der erste Clemensbrief (Kommentar zu den Apostolischen Vätern 2; Göttingen: Vandenhoeck \& Ruprecht, 1998) 75-8.

${ }^{5}$ For problems of the traditional dating, see L. L. Welborn, 'On the Date of First Clement', BR 29 (1984) 35-54. Andrew Gregory argues that there are no convincing arguments for a more exact dating than between c. 70 and c. 140 CE; see 'Disturbing Trajectories: 1 Clement, the Shepherd of Hermas and the Development of Early Christianity', Rome in the Bible and the Early Church (ed. P. Oakes; Carlisle, UK/Grand Rapids, MI: Paternoster/Baker Academic, 2001) 142-66.

${ }^{6}$ On the use of deliberative rhetoric in the letter, see O. M. Bakke, 'Concord and Peace': A Rhetorical Analysis of the First Letter of Clement with an Emphasis on the Language of Unity and Sedition (WUNT II 143; Tübingen: Mohr Siebeck, 2001) 320-1.

${ }^{7}$ While the letter itself names no author, the attribution of the letter to 'Clement' is relatively early and consistent (see below n. 62). Lona argues that there is no reason to doubt the attribution of the letter to a person called Clement, but his function in Rome is a different matter. According to Lona, the literary quality of the writing and the influence and reception of the letter suggest that this Clement was an important figure in Rome (Clemensbrief, 71-2). Holmes similarly views Clement as 'a (if not the) leading figure' among Roman presbyters and bishops; see M. W. Holmes, Apostolic Fathers: Greek Texts and English Translations (Grand Rapids, MI: Baker, 2007³) 35.
} 


\section{Mutual Authorisation in 1 Clement}

Authority is not an inherent feature of texts - perhaps apart from the fact that in the ancient world, there was a certain respect towards anything written down. ${ }^{8}$ Instead, authority is a relational concept: a text is authoritative for someone in a certain context. ${ }^{9}$ A writer may produce a text that makes claims to authority: it imposes its authority on the readers, demanding respect, recognition and acceptance. Yet it is the readers who accept or deny these claims by either submitting under the authority of the text or by rejecting the need to do so. ${ }^{10}$ The authority of a text is not static but can be enhanced, transformed, questioned or downplayed by the readers and by the newer texts that they compose.

Hanne von Weissenberg aptly describes the dynamics between a source text and a later writing that cites, paraphrases or rewrites it as a process of mutual authorisation: ${ }^{11}$ the base text authorises the new text, and the new writing reinforces the authority of the old one. The new writing draws from the authority of the older one, but at the same time, when writers cite and reframe a piece of older tradition and imply that it has transformative potential, they confirm its continuing relevance and meaningfulness for the community. ${ }^{12}$ Authority flows in both directions but this flow is not 'symmetrical'. The confirmed authority of the traditional text is of different kind than the authority that the newer composition acquires by means of interpretation.

The concept of mutual authorisation is useful for examining the two-way flow of authority in 1 Clement. The immediate relevance and transformative potential of the Jewish scriptures is the starting point for 1 Clement's call for humility, concord, peace, repentance and good order. ${ }^{13}$ Clement's use of the texts is first and foremost paraenetic: one scriptural character after another is taken up as an example to be imitated and emulated. Allegorical interpretation plays almost no role

\footnotetext{
${ }^{8}$ However, see George Brooke's structural analysis of 'actantial' authority that 'seems to inhere within a text as it is passed from one generation to another' ('Authority and the Authoritativeness of Scripture: Some Clues from the Dead Sea Scrolls', Revue de Qumran 100 (2012) 507-23, at 509-14). Brooke argues that 'texts have authority in the dynamics of their construction'. Brooke's analysis is enlightening, and I would only make the minor reservation that 'texts make claims to authority' (rather than 'have' it). As for connections between the writtenness of texts and their authority in a Jewish context, see H. Najman, 'Interpretation as Primordial Writing: Jubilees and its Authority Conferring Strategies', Past Renewals: Interpretative Authority, Renewed Revelation, and the Quest for Perfection in Jewish Antiquity; Supplements to the Journal for the Study of Judaism 53; Leiden: Brill, 2010) 39-73, at 23: 'In the Second Temple period, a text's being authored or dictated (rather than, for example, an idea, vision, or law being orally communicated) by this or that figure, and a text's being transmitted by a line of faithful tradents, became marks of its authority.'

${ }^{9}$ H. von Weissenberg, 'Defining Authority', In the Footsteps of Sherlock Holmes: Studies in the Biblical Text in Honour of Anneli Aejmelaeus (ed. K. d. Troyer, et al.; Leuven: Peeters, 2014) 679-95, at 690. For a model of authority as a complex relation with several variables, see J. Opsomer and A. Ulacco, 'Epistemic Authority in Textual Traditions: A Model and Some Examples from Ancient Philosophy', Shaping Authority, 21-46, at 32.

${ }^{10}$ Brooke, 'Authority and the Authoritativeness', 515: '[A]s far as matters of authority go there is commonly a two-way process: authority is sometimes simply imposed on hearers or readers by authors and their texts (as with papal decrees), but generally it is also conferred through the assent of the hearer of reader.' Thus, 'any text's authority is also a construct of the interplay that runs through from author to editor to audience or readership and back again.' (p. 519).

${ }^{11}$ von Weissenberg, 'Defining Authority', 685. Several other scholars describe the same process with different concepts; see the following footnote as well as Opsomer and Ulacco, 'Epistemic Authority', 36.

${ }^{12}$ For this dynamics in the Dead Sea Scrolls, see G. J. Brooke, 'Between Authority and Canon: The Significance of Reworking the Bible for Understanding the Canonical Process', Reworking the Bible: Apocryphal and Related Texts at Qumran (ed. E. G. Chazon, et al.; STDJ 58; Leiden: Brill, 2005) 85-104, at 85, 98; F. García Martínez, 'Rethinking the Bible: Sixty Years of Dead Sea Scrolls Research and Beyond', Authoritative Scriptures in Ancient Judaism (ed. M. Popović; Supplements to the Journal for the Study of Judaism 141; Leiden: Brill, 2010) 19-36, at 28-9. For examples in the Wisdom of Solomon, see A. T. Glicksman, "Set Your Desire on My Words": Authoritative Traditions in the Wisdom of Solomon', Scriptural Authority in Early Judaism and Ancient Christianity (ed. I. Kalimi, et al.; Deuterocanonical and Cognate Literature Studies 16; Berlin: De Gruyter, 2013) 167-82, at 180-1.

${ }^{13}$ For Clement's ways of referring to 'the scriptures', see below p. 10.
} 
in the letter: ${ }^{14}$ Clement uses the narratives directly, without explicating hidden meanings, to exhort and to admonish. By doing so, Clement demonstrates the immediate relevance of the Jewish scriptures for Christian life. At the same time, the scriptures lend weight to the demand of the Roman congregation that the rebels in Corinth should stand down, deposed leaders be returned to their positions, and peace be restored. The writings that Clement uses therefore authorise the message of the letter and strengthen the authority of its writer and senders, and the letter in turn implicitly strengthens the authoritativeness of these writings: it shows that they are integral for settling weighty matters such as leadership in the Christian communities. It appears that Clement does not expect anyone to refute the value of the writings he cites, but Marcion's approach a little later demonstrates that the authoritativeness of the Jewish writings was not unassailable.

Recently scholars have drawn attention to the connections between the authoritativeness of texts, their study, and instruction: '[W]ithout being studied, the ancient books - the Scriptureswould remain silent objects. ${ }^{15}$ Von Weissenberg's concept of mutual authorisation is particularly apt for describing this process. New writings that study, interpret, and actualise older ones keep the old writings alive and relevant to new generations, thus ensuring their continuing authoritativeness. A new writing, on the other hand, may gain authority exactly because it draws from authoritative writings or is useful for their study. ${ }^{16} 2$ Tim 3.16 famously makes a straightforward connection between instruction and the inspired nature of the scriptures: 'All scripture is inspired by God ( $\left.\theta \varepsilon \circ \sigma^{\prime} \tau \varepsilon \varepsilon \sigma \tau \circ \varsigma\right)$ and is useful for teaching, for reproof, for correction, and for instruction in righteousness.' 17

The aspect of instruction is marked in 1 Clement. The writer makes his use of authoritative writings transparent to a greater extent than Paul, for example. The paraphrases of narratives are made accessible, and nearly all of the quotations are marked out with an introductory formula so that the audience cannot miss them. It appears that Clement understands that scriptural argumentation can be authoritative only if the audience is able to recognise it as scriptural. The numerous remarkably long quotations may also reflect educational objectives: it is as if Clement intentionally selects and offers his audience certain core texts that are useful for study and memorisation. Despite the wealth of scriptural material that the letter provides for study and discussion, the audience is not left to grapple with it alone, for Clement has a very pedagogical approach to introducing quotations and narratives. Compared with Paul, Clement is more explicit, careful and patient in his explanations, leaving little room for misunderstandings. ${ }^{18} \mathrm{He}$ sketches the narrative context before quoting, and afterwards he almost systematically draws a conclusion that highlights the main point of the scriptural reference. 1 Clem 17.1-19.1 is a fine example. Clement begins with Abraham's exemplary humility and continues to Job:

1 Clem 17.3-4: Again, about Job it is thus written: 'Job was righteous and blameless, one who was true and who honoured God and kept off from all evil.' (Job 1.1). But he accuses himself and says: 'No one is clean from filth, not even if his life is only one day long.' (Cf. Job 14:4, 5). (Moses's and David's examples with quotations

\footnotetext{
${ }^{14}$ The only clear example of allegory is when Rahab's scarlet scarf is connected with Christ's blood (12.7-8); cf. D. A. Hagner, The Use of the Old and New Testaments in Clement of Rome (NTSup 34; Leiden: Brill, 1973), 130.

${ }^{15}$ A. van der Kooij, 'Authoritative Scriptures and Scribal Culture', Authoritative Scriptures in Ancient Judaism (ed. M. Popović; Supplements to the Journal for the Study of Judaism 141; Leiden: Brill, 2010) 55-71, at 57.

${ }^{16}$ See the discussion of Sirach's prologue in van der Kooij, 'Authoritative Scriptures', 56-7, 60.

${ }^{17}$ It has been argued that education is a setting that promotes the processes of canonisation in antiquity, since education necessitates a curriculum and a curriculum defines the core writings (see G. J. Brooke, 'Canonisation Processes of the Jewish Bible in the Light of the Qumran Scrolls', 'For it is Written': Essays on the Function of Scripture in Early Judaism and Christianity (ed. J. Dochhorn; Early Christianity in the Context of Antiquity 12; Frankfurt am Main: Peter Lang, 2011) 13-35, at 29-33). This observation is also highly interesting for the development of early Christianity. Yet at the time of 1 Clement, one can hardly speak of a curriculum of Christian teaching.

${ }^{18}$ For comparison, see Rom 10.18-21, where the quotation formulae are somewhat ambiguous and Paul never concludes what one should learn from the quotations. The audience is left to deduce the point.
} 
follow until it is time for a conclusion) 19:1: The humility and sense of lowliness that comes from obedience, thus attested by so many renowned people, has improved not only us but also the generations before us. ${ }^{19}$

The focus on scriptural teaching and instruction concerning Christian virtues is understandable if the letter was from the very beginning intended to reach a larger audience than the Corinthian congregation. Despite the fact that 1 Clement is a genuine letter addressed to a particular situation and with a certain aim, the main themes of the exhortation are also more generally applicable to Christian life. The length and thoroughness of the scriptural journey suggests that the letter strives for more than just settling the Corinthian crisis of leadership. The author and senders of the letter may have sent copies of the letter to other congregations (and assumed that the Corinthians may do that as well), and in all probability they kept a copy in Rome. By the time 1 Clement was composed, Paul's letters were already circulating in a large geographic area. An edifying letter useful for instruction concerning both the Jewish scriptures and their relevance for Christian life could be expected to circulate beyond its original audience. ${ }^{20}$

\section{The Authoritativeness and Sacredness of the Scriptures in 1 Clement}

Clement appears to take for granted that the Jewish scriptures are authoritative for his audience. Yet what is this authoritativeness based on and from where does it derive? Recently, scholars have put some effort into differentiating between different sources of authority and into describing strategies for acquiring authority. When examining the basis for scriptural authority, Georg H. van Kooten makes a helpful distinction between divine oracular authority, prophetic authority, and ancestral authority (examples of all three will follow below). ${ }^{21}$ Hindy Najman uses the concept of an authority-conferring strategy to describe a writing's claims to authority. The concept is useful for descriptive purposes, and it does not presuppose a fixed categorisation of strategies: one literary work can use several distinct but connected authority-conferring strategies. ${ }^{22}$

Scholars have also drawn attention to terminological questions and to emic and etic usage of words connected with authority. Jan Bremmer criticises the common scholarly practice of projecting the idea of the sacredness of scripture onto ancient writings that do not use such vocabulary themselves. ${ }^{23}$ In the vocabulary of Clement, however, the sacredness and holiness of the scriptures is explicit. In the following, I will examine various sources for authority in $1 \mathrm{Clement}$ according to van Kooten's distinction between divine oracular authority, prophetic authority and ancestral origin. Later in the article I will examine other factors that play a role when a text is construed as authoritative.

\subsection{Divine Oracular Authority and the Sacredness of the Scriptures}

The basis for divine oracular authority is the idea that the scriptures contain God's utterances. In 1 Clement, this is the source not only for the authority of the scriptures but also for their sacredness. In 1 Clement, 'the scriptures' is a meaningful entity (cf. $45.2 ; 53.1){ }^{24}$ which is not the same thing as to say that the author envisioned a closed canon. In quotation formulae, Clement

\footnotetext{
${ }^{19}$ The translations of primary texts are my own.

${ }^{20}$ For the practices concerning the circulation of letters in the first and second centuries among Christians, see H. Y. Gamble, Books and Readers in the Early Church: A History of Early Christian Texts New Haven: Yale University Press, 1995) 96-101, 108-12.

${ }^{21}$ G. H. van Kooten, 'Ancestral, Oracular and Prophetic Authority: “Scriptural Authority” according to Paul and Philo', Authoritative Scriptures in Ancient Judaism (ed. M. Popović; Supplements to the Journal for the Study of Judaism 141; Leiden: Brill, 2010) 267-308.

${ }^{22}$ See Najman, 'Interpretation as Primordial Writing', 40.

${ }^{23}$ J. N. Bremmer, 'From Holy Books to Holy Bible: An Itinerary from Ancient Greece to Modern Islam via Second Temple Judaism and Early Christianity', Authoritative Scriptures in Ancient Judaism (ed. M. Popović; Supplements to the Journal for the Study of Judaism 141; Leiden: Brill, 2010) 327-60, at 328.

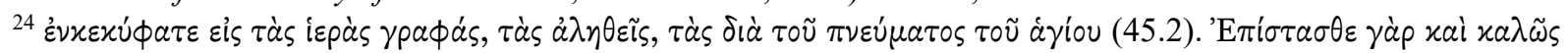

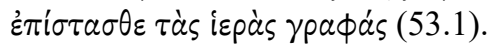




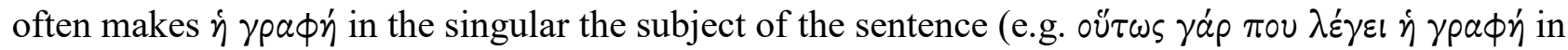
42.5), thus implying that $\dot{\eta} \gamma \rho a \phi \dot{\eta}$ is an entity that encompasses the individual writings. Yet he can also use $\dot{\eta} \gamma \rho a \phi \eta^{\prime}$ of a particular, defined passage (e.g. 23.3).

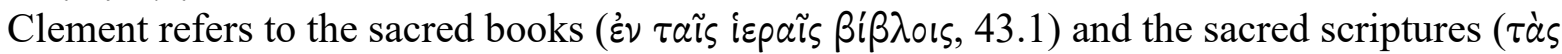
iєpàs $\gamma p a \phi a ́ s, 45.2 ; 53.1)$, and introduces quotations twice with the phrase 'the holy word says'

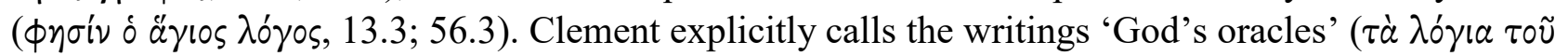
$\theta \varepsilon 0 \tilde{u}, 53.1$, cf. 13.4; 19.1; 62.3), and unlike Paul, who never explicitly presents God as the speaker of a quotation, ${ }^{25}$ Clement repeatedly uses variations of the phrase 'God says' (e.g. 33.5). In one quotation, he makes Christ the speaker of a psalm quotation 'through the Holy Spirit' ${ }^{26}$ The idea of the mediating role of the Holy Spirit is also repeated in connection with 'the sacred scriptures' ( $\delta i \dot{\alpha}$

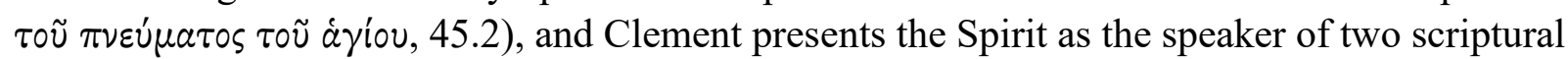
quotations $(13.1 ; 16.2) .{ }^{27}$ That the Jewish scriptures contain divine oracles and utterances by God, Christ and the Holy Spirit and that they are mediated by the Holy Spirit, appear to be for Clement the most essential factors that make them sacred.

1 Clement merely quotes divine utterances already recorded in authoritative writings, whereas other early Christian writers both before and after Clement claimed to have access to new revelations and could relay so far unheard divine utterances. Paul conveys words from Christ to the Corinthian congregation (1 Cor 7.10; cf. 11.23), and the Shepherd of Hermas makes claims to at least angelic authority. Revelation declares that it is 'the revelation of Jesus which God gave to him' (Rev 1.1). ${ }^{28}$ Revelation directly claims to be a divine oracle and therefore scripture whose wording may not be altered (28.18-19), whereas in 1 Clement, the divine oracles authorise the Jewish scriptures and only indirectly the letter itself that quotes and interprets them.

\subsection{Prophetic Authority}

Van Kooten's category of prophetic authority does not refer so much to the role of the prophet as the faithful recipient and transmitter of the divine oracles. Rather, in Philo's terms, true prophecy means that the prophet speaks in his own person under divine inspiration. Moses, according to Philo, is occasionally a mere recipient of divine speech, whereas at other times he is possessed by God but speaks in his own person, thus functioning as a prophet in the actual sense of the word. ${ }^{29}$ Van Kooten suggests that Paul makes a similar distinction between his own prophetic statements and Christ's words that he mediates (cf. 1 Cor $7: 10,12 ; 25 ; 39-40) .{ }^{30}$ Paul also makes the distinction concerning scriptural prophecies: 'Paul attributes the various Jewish Scriptures to their

\footnotetext{
${ }^{25}$ Though see the quotation formulae in Rom 9.15, 25; 2 Cor 6.2 in which God is the implicit subject; for discussion, see K. Kujanpää, The Rhetorical Functions of Scriptural Quotations in Romans: Paul's Argumentation by Quotations (NTSup 172; Leiden: Brill, 2019) 98.

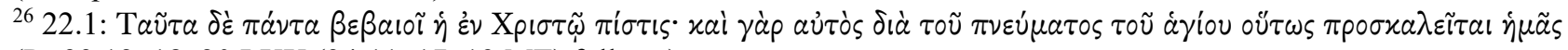
(Ps 33.12-18, 20 LXX (34:11-17, 19 MT) follows).

${ }^{27} \mathrm{Cf}$. Heb 3.7; 10.15. The mediation of the Spirit alone is not, however, an indication of the status of a text as sacred scripture, for Clement uses it of his own letter as well: 'For you will give us great joy and gladness if you obey what we

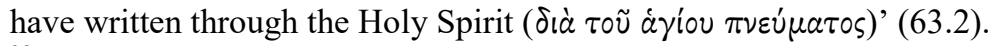

${ }^{28} \mathrm{~T}$. Nicklas makes an enlightening observation concerning the authority-conferring strategies in Revelation in relation to quotations: 'Apocalypse does not offer explicit quotations from the Torah or from the Prophets; someone who claims to record a revelation received from God and Christ respectively, who directly envisions heaven, does not need to quote Scripture as an authority. Actually he cannot do it, in a manner of speaking, unless he wants to destroy at the same time the fiction of the immediacy of what was revealed to him.' "The Words of the Prophecy of this Book": Playing with Scriptural Authority in the Book of Revelation', Authoritative Scriptures in Ancient Judaism (ed. M. Popović; Supplements to the Journal for the Study of Judaism 141; Leiden: Brill, 2010) 309-26, at 322.

${ }^{29}$ For Philo's distinction between different kinds of oracles, see van Kooten, 'Ancestral, Oracular and Prophetic Authority', 293-6.

${ }^{30}$ van Kooten, 'Ancestral, Oracular and Prophetic Authority', 298.
} 
human, prophetic author and it is only the direct oracular speeches of God in these writings that Paul regards as the words of God as such.' ${ }^{31}$

No such distinctions between various degrees of authoritativeness among the scriptural writings are visible in 1 Clement. The letter never takes a critical stance towards any part of scriptural tradition, and therefore it has no need to question the authority of one scriptural passage in favour of another. It is not that all quotations from the scriptures represent divine oracles, for 1 Clement frequently quotes human responses as well. These quotations serve as examples of humility and other virtues (cf. 1 Clem 17.3-4 quoted above), and it is important for their authoritativeness that they come from scriptural characters 'of renown' (e.g. 17.1). As a whole, however, the letter shows relatively little interest in prophetic authority.

\subsection{Antiquity and Ancestral Origin}

In the ancient world, emphasising the antiquity or the ancestral origin of traditions was a common authority-conferring strategy. ${ }^{32}$ In 1 Clement, the antiquity of the scriptures is not a particularly important theme, yet it does surface a couple of times $(5.1 ; 19.1$; for 42.5 see below). As for ancestral authority, although the addressees of the letter in Corinth were probably mostly non-Jews, Clement uses the phrases 'our father Jacob' (4.8) and 'our father Abraham' (31.2) without any explanation or hints of addressing a controversial matter. ${ }^{33}$ The overall impression is that Clement and his addressees are direct heirs of the patriarchs and of the scriptures, and the Jewishness of the tradition is simply not a problem that should be discussed (see 1 Clem. 31:432:2). ${ }^{34}$ There are no explicit supersessionist arguments in the letter; in fact, as Annie Jaubert observes, it is as if the Jews did not exist. ${ }^{35}$ By presenting Abraham and Jacob as the ancestors of the recipients of the letter, Clement ensures that he can draw from authority based on ancestral origin, a form of authority widely recognised in the ancient world. From the perspective of 1 Clement, it is not the Jewish scriptures that are quoted, but the tradition of 'our fathers'.

\section{The Immutability of Authoritative Texts}

One concept that occasionally emerges when the authoritativeness, sacredness or canonicity of writings is discussed is that of immutability. ${ }^{36}$ The assumed connection between authority and immutability is that the more authoritative and 'canonical' the writing, the more fixed its wording becomes. This view may well be justified when discussing large-scale redaction in a literary work or some cases of textual transmission, such as the development of the Masoretic text. Yet it appears that in several cases, and particularly when new literary entities cite earlier writings, one should not

\footnotetext{
${ }^{31}$ van Kooten, 'Ancestral, Oracular and Prophetic Authority', 305. For an example of Paul assuming various degrees of authority in different passages of the scriptures, see the discussion of Rom 10.5-8 in Kujanpää, Rhetorical Functions, $161-2$.

${ }^{32}$ van der Kooij, 'Authoritative Scriptures', 55; van Kooten, ‘Ancestral, Oracular and Prophetic Authority', 267.

${ }^{33}$ As Carleton Paget argues, 'the atmosphere of his epistle is both Jewish and strongly scriptural, and is so in an untroubled and confident manner with no sense that the Christian appropriation of the scriptures is a problem.' J. Carleton Paget, '1 Clement, Judaism, and the Jews', Early Christianity 8 (2017) 218-50, at 224.

34 'We are the portion ( $\mu \varepsilon p i$ ' $)$ of the Holy One', Clement writes, just after quoting Deut. 32:8-9 ('his people, Jacob, became the Lord's portion'; see 1 Clem 29:1-30:1).

${ }^{35}$ Jaubert, Clément de Rome, 30. For what this might tell of the Jewish-Christian relations in Rome, see Carleton Paget,

'1 Clement', 248-50.

${ }^{36}$ Textual stability is demanded by some biblical texts themselves: the Textsicherungsformel in Deut 4.2 and 12.31/13.1 (often unhelpfully called 'canon formula') forbids any additions or omissions to the commandments. Based on these passages, Revelation declares that God himself will punish anyone making changes to the book (Rev 22.18-19).
} 
assume a straightforward correlation between the authority of texts and the immutability of their wording. ${ }^{37}$

Although both Paul and Clement call the scriptures sacred and consider them to contain divine utterances, they seem to have no scruples whatsoever in changing the wording of a quotation if the adaptation helps to better highlight the relevance of the quotation. ${ }^{38}$ In doing this, they are, of course, merely making use of the common literary techniques of their time. ${ }^{39}$ My point is that in numerous cases they do not appear to treasure the exact wording even in cases in which it is reasonable to assume that they could have quoted accurately. While numerous quotations in 1 Clement follow the Septuagint almost verbatim, there is no shortage of examples in which Clement seems to adjust the wording for the sake of style or coherence. The inaccuracy of such quotations is often explained by suggesting that Clement relies on his memory alone. If that is the case, Clement's memory appears to regularly improve the style of the quotations stored in it, as the following examples show.

The quotation from Exod 32.32 in 1 Clem 53.4 is a fine example of a free rendering that makes the quotation more impressive. Clement first describes the narrative context of the golden calf incident in his own words and quotes God's plan to destroy the people and to create a new one (Deut 9.13-14). Clement's quotation of Moses's answer is much bolder than in the Septuagint. In the following table, the verbal agreements between the two are in bold.

\begin{tabular}{|c|c|}
\hline 1 Clem $53.4^{40}$ & Exod $32.31-32^{41}$ \\
\hline 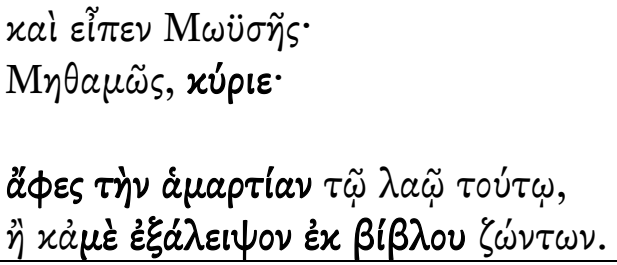 & 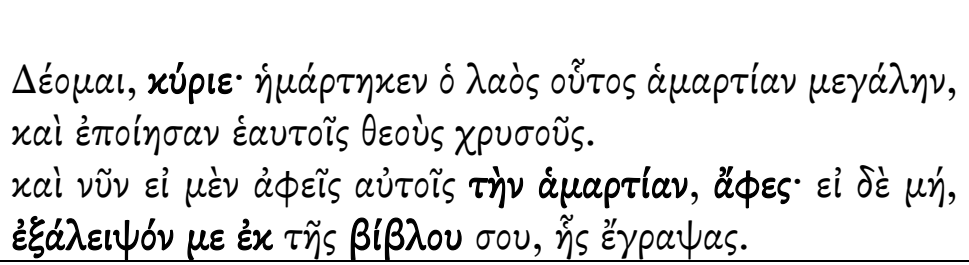 \\
\hline $\begin{array}{l}\text { And Moses said: } \\
\text { By no means, Lord! } \\
\text { Forgive this people their sin, } \\
\text { or wipe me also out of } \\
\text { the book of the living! }\end{array}$ & $\begin{array}{l}\text { I beg you, Lord. This people has sinned a great sin and } \\
\text { made for themselves golden gods. And now, if you } \\
\text { forgive them the sin, forgive. But if not, } \\
\text { wipe me out of } \\
\text { your book that you have written. }\end{array}$ \\
\hline
\end{tabular}

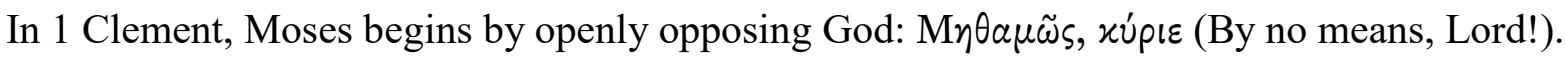
His request is a direct demand without any conditional clauses and more concise and dramatic than the reading of the Septuagint. Clement then praises Moses precisely for his boldness: 'What mighty

\footnotetext{
${ }^{37}$ Similarly, von Weissenberg, 'Defining Authority', 681-4. To take an example from the Christian transmission of the Septuagint, the edition that bears the name of Lucian of Antioch makes stylistic changes to the wording of Septuagint around 300 .

${ }^{38}$ For Paul, see D.-A. Koch, Die Schrift als Zeuge des Evangeliums: Untersuchungen zur Verwendung und zum Verständnis der Schrift bei Paulus (BHT 69; Tübingen: J. C. B. Mohr 1986) 186-7; C. D. Stanley, Paul and the Language of Scripture: Citation Technique in the Pauline Epistles and Contemporary Literature (SNTSMS 74; Cambridge: Cambridge University Press, 1992) 259-60; Kujanpää, Rhetorical Functions, 334-6, 339-40. For Clement, see Hagner, Use of the Old and New Testaments, 78-9.

${ }^{39}$ For the quotation technique of Paul's and 1 Clement's contemporaries, see Stanley, Paul and the Language, 267-350.

${ }^{40}$ The Greek text of 1 Clement is quoted according to Holmes, Apostolic Fathers.

${ }^{41}$ No Greek variants that would offer support for 1 Clement's wording are preserved. The Greek text is cited according to John William Wevers's edition Exodus. Vetus Testamentum Graecum: Auctoritate Academiae Scientarium Gottingensis editum (Vandenhoeck \& Ruprecht: Göttingen, 1991).

${ }^{42}$ Clement of Alexandria quotes the same passage in verbatim agreement with 1 Clement (Stromateis 4.19 (118.3)), but since he was a great admirer of the letter, his quotation does not support a hypothesis of an otherwise unattested reading of the passage.
} 
love! What unsurpassable perfection! The servant speaks boldly to the Lord' (53.5). According to Clement, Moses's exemplary attitude and solidarity with his community have direct consequences. The rebels in Corinth should show similar love and, for the sake of concord, submit to the duly appointed presbyters and leave the congregation (54.1-2). While improving the wording of the Septuagint is by no means vital for Clement's point, it makes Moses sound more heroic and thus worthier of imitation. There is no reason to doubt that 1 Clement has modified the wording for the

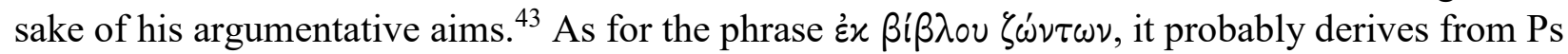
68.29 (69.29 MT), a psalm quoted in 1 Clem 52:2. ${ }^{44}$ Again, 'the book of the living' is more dramatic than 'the book you have written'. 45

In the vast majority of quotations it is implausible to explain Clement's readings by appealing to the textual plurality of the first century and suggesting that Clement preserves an otherwise unattested variant reading. This is because the deviations from the Septuagint frequently make sense in the context of quotation in 1 Clement, whereas it would be difficult to find a reason for them within the textual transmission of the Septuagint. The quotation from Ezek 33.11 in 1 Clem 8.2 highlights this. The quotation also exemplifies Clement's creative use of introductory formulae that can be rather unformulaic. He frequently tailors formulae for a particular context in order to give the audience information concerning the theme, context or speaker: 'the Master of the universe

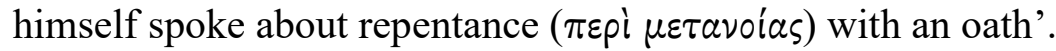

\begin{tabular}{|c|c|}
\hline 1 Clem 8.2 & Ezek 33.11 LXX ${ }^{46}$ \\
\hline 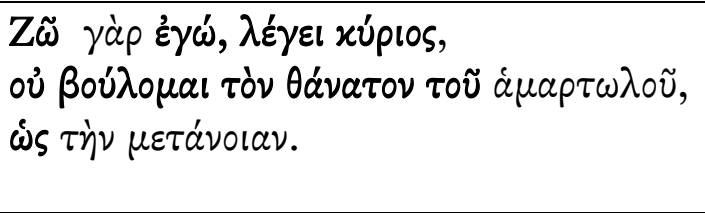 & 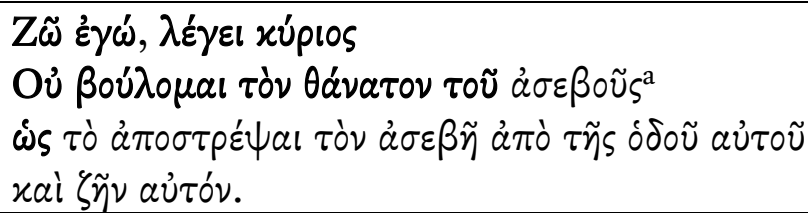 \\
\hline $\begin{array}{l}\text { For as surely as I live, says the Lord, } \\
\text { I do not desire the death of the sinner } \\
\text { so much as his repentance. }\end{array}$ & $\begin{array}{l}\text { As surely as I live, says the Lord, } \\
\text { I do not desire the death of an impious person, } \\
\text { but that the impious person turns back from his } \\
\text { way and lives. }\end{array}$ \\
\hline
\end{tabular}

At the end of the quotation, Clement summarises Ezekiel's lengthy formulation simply with $\tau \dot{\eta} \nu \mu \varepsilon \tau \dot{\alpha} \nu \circ เ \alpha \nu$. Although this makes the quotation significantly shorter, the substitution has relatively little effect on the message. It has been suggested that Clement quotes here not the book of Ezekiel as such, but an apocryphal work attributed to Ezekiel. ${ }^{47}$ Yet $\mu \varepsilon \tau \alpha^{\prime} v o l \alpha$ is a word that occurs repeatedly in the context of the quotation in 1 Clement: in addition to the quotation formula, the word is used in each of the five previous verses $(7.4 ; 7.5 ; 7.6 ; 7.7 ; 8.1)$. The importance of the

\footnotetext{
${ }^{43}$ Lona views this as a case of indirect quotation that demonstrates the author's ability to create a new independent formulation (Clemensbrief, 551). The letter, however, introduces Moses's reply as a direct quotation.

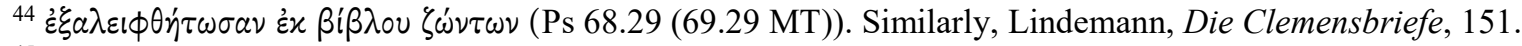

${ }^{45}$ In addition, as Rothschild (New Essays, 89) argues, the substitution may create a contrast between those who rebelled against Moses and went down to Hades where 'death is their shepherd' (1 Clem 51:4), and with Moses as the shepherd who keeps his flock in the book of the living.

${ }^{46}$ The Greek text is cited according to Joseph Ziegler's edition Ezechiel. Vetus Testamentum Graecum: Auctoritate Academiae Scientarium Gottingensis editum (Vandenhoeck \& Ruprecht: Göttingen, 20154).

${ }^{47}$ Lona, Clemensbrief, 187; Hagner, Use of the Old and New Testaments, 54 (as one option). Yet the arguments for this appear feeble. The main argument for the apocryphon hypothesis is that the following quotation in 8.3 does not agree with any passage of the canonical Ezekiel. However, it could be Clement's own compilation, a free paraphrase of Ezek 33 (cf. Holmes in his edition). Lona observes that when Clement of Alexandria quotes the same passage in $1 \mathrm{Clem} 8.2$, he does not name the source. Yet this is hardly convincing evidence for postulating a new source text.
} 
word for Clement's argumentation suggests that he is responsible for summarising the end of Ezek

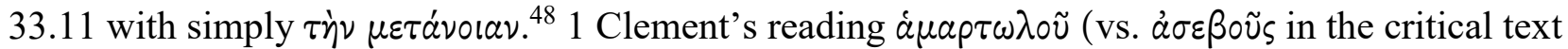
of Ezekiel), in contrast, may represent an inner-Greek variant in the text known to Clement. ${ }^{49}$

These quotations show that the inaccuracy of certain quotations in 1 Clement is unlikely to be accidental. It is perfectly plausible that Clement did not systematically check the wording of every quotation from a manuscript but chose to quote freely, relying on his memory and slightly improving the style of what he remembered. ${ }^{50}$ However, that he chose to rely on his memory already demonstrates that the immutability and fixed wording of 'the sacred scriptures' and 'the holy word' were not for him a primary concern. If the exact wording of the scriptures as such were sacred, it would be problematic to change it. Yet Clement appears to share Paul's approach to the matter: alterations of the wording may help to highlight the relevance of a quotation for the readers of the letter, and this relevance appears to be much more important than any ideal of accurate quoting.

So far I have examined the authority of the writings cited and paraphrased in 1 Clement. In the following pages, I will first show how the letter uses these writings to authorise the status of the deposed leaders and to legitimise hierarchical structures. I will then turn to the authority and reception of the letter itself in order to illuminate the connections between authority and the author.

\section{Divinely Instituted Bishops and Deacons in Isaiah}

Good order that corresponds to the divine will is an important theme that Clement keeps returning to in the letter $(20.1-11 ; 33.3 ; 37.2 ; 61.1) .{ }^{51}$ In chapter 42 he argues for a hierarchical order in which 'Christ is from God, and the apostles are from Christ. Both, therefore, came of the will of God in good order.' (42.2) The chain continues: bishops and deacons were then appointed by the apostles themselves (42.4). This implies that the troublemakers in Corinth are rebelling against apostolic authority, which derives from Christ. Yet Clement makes an even bolder claim by means of a direct quotation: "And this was no new thing they (=the apostles) did, for indeed something had been written about bishops and deacons many years ago; for somewhere thus says the scripture

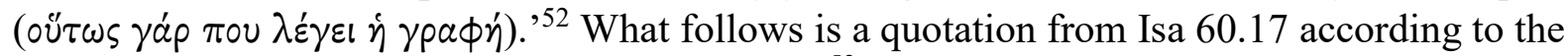
Septuagint, but with some striking modifications. ${ }^{53}$

\begin{tabular}{|c|c|}
\hline 1 Clem 42.5 & Isa $60.17 \mathrm{LXX}^{54}$ \\
\hline 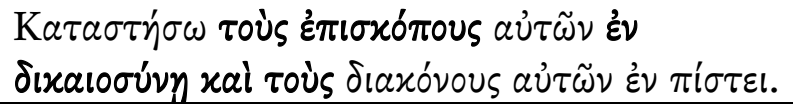 & 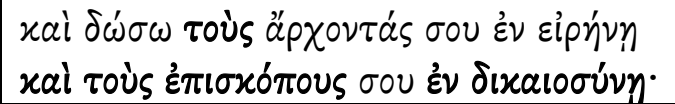 \\
\hline $\begin{array}{l}\text { I will appoint their bishops in righteousness } \\
\text { and their deacons in faith. }\end{array}$ & $\begin{array}{l}\text { And I will appoint your rulers in peace } \\
\text { and your overseers in righteousness. }\end{array}$ \\
\hline
\end{tabular}

\footnotetext{
${ }^{48}$ Similarly, Lindemann, Die Clemensbriefe, 46.

${ }^{49}$ In the Greek Ezekiel, both $\alpha \sigma \varepsilon \beta \eta \dot{s}$ and $\alpha \mu \alpha \rho \tau \omega \lambda$ ós are used to translate wiָׁ, which explains how such a variant may have arisen.

50 For example, in 1 Clem 53.3 the long quotation of God's speech follows Deut. 9.13-14 almost verbatim. Yet in Deuteronomy, Moses does not answer. It is possible that Clement consulted Deuteronomy 9 but quoted Moses's answer in Exodus from memory.

${ }^{51}$ See further H. O. Maier, The Social Setting of the Ministry as Reflected in the Writings of Hermas, Clement and Ignatius (Studies in Christianity and Judaism 12; Waterloo, Ontario: Wilfrid Laurier University Press, 2002) 120-1, 131.

${ }^{52}$ Clement also uses the indefinite $\pi \circ v^{\prime}$ in quotation formulae in $15.2 ; 21.2 ; 26.2 ; 28.2 ;$ cf. Heb 2.6; 4.4 .

${ }^{53}$ The Masoretic text makes a rather different statement, not referring to human agents at all: 'I will appoint peace as

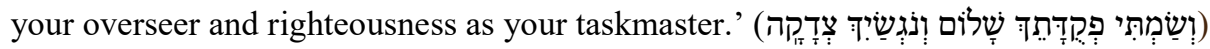

${ }^{54}$ No Greek variants that would offer support for 1 Clement's wording are preserved. The Greek text is cited according to Joseph Ziegler's edition Isaias. Vetus Testamentum Graecum: Auctoritate Academiae Scientarium Gottingensis editum (Vandenhoeck \& Ruprecht: Göttingen, 1983³).
} 
In the Septuagint, the future time of prosperity is marked by divinely given rulers and

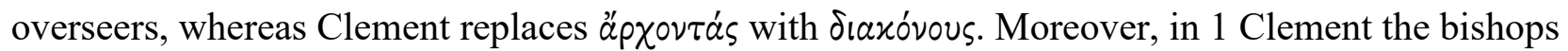
and deacons are not 'given' 'in peace' but 'appointed' 'in faith'. The textual tradition of the Septuagint shows no variation in these details, nor does the wording of 1 Clement agree with any other known textual tradition. It is easy to see how the substitutions correspond to Clement's argumentative aims: through them, Clement can argue that the scriptures show that it is ultimately God himself who appoints bishops and deacons, in righteousness and in faith. Disobeying them is therefore rebellion against divine order. The substitution of $\delta i \delta \omega \mu$ with $\chi^{\prime} \theta_{i}(\sigma \tau \eta \mu l$ ties the quotation with Clement's vocabulary in the surrounding context, for the same verb is also used of

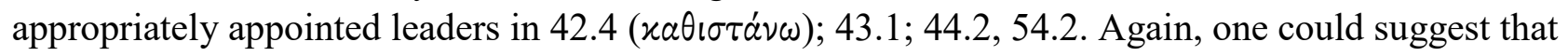
Clement simply relies on his memory, particularly as his quotation formula may reflect some uncertainty concerning the source text. Hagner suggests that he confuses Isaiah with Phil 1.1 where

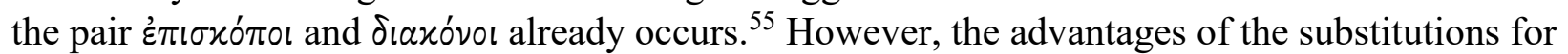
Clement's argument are so obvious that his memory would appear to be conveniently eclectic. ${ }^{56}$

In this case, the connections between scriptural argumentation, power structures and social order are exceptionally straightforward. A scriptural quotation is used to legitimise hierarchical structures by confirming their ancient and divine origin, ${ }^{57}$ which simultaneously strengthens the position of the author and the senders of the letter (who are in a leading position as well). As far as I know, no writer in the early church was dismayed by the inaccuracy of Clement's quotation or by his attempt to make Isaiah defend the replaced leaders in Corinth. ${ }^{58}$ And why would they have been? Clement argues for good order and manages to increase the authority of the established office holders by demonstrating a fundamental continuity between their ministry and God's promise in the authoritative scriptures.

\section{The Author and Authority}

In our time, the idea of authenticity is integral to a text's authority: we often tend to think that a text that claims false authorship is inauthentic and thus its authority is severely compromised. It is, however, problematic to impose this view on ancient material. ${ }^{59}$ The phenomenon of pseudonymous attribution is too complex to be discussed in this article, but Najman's concept of 'a discourse tied to a founder' deserves to be quoted here as an alternative to modern conceptions of fraudulence and

\footnotetext{
${ }^{55}$ Hagner, Use of the Old and New Testaments, 67, 106, 228. Evans develops Hagner's arguments further and suggests that the quotation 'has been heavily influenced (perhaps unconsciously) by ecclesiastical tradition concerning church offices', reflected in Acts 6:1-6. C. Evans, 'The Citation of Isaiah 60:17 in I Clement', Vigiliae Christianae 36 (1982) 105-7, at 106. Jaubert, Clément de Rome, 43, for her part, argues that Clement relies on a translation used in his social context. Yet it is questionable whether Clement's version can be called a translation. I wonder, moreover, why it is better to attribute the misquotation to some unknown circle in Rome than to Clement. It is undeniable that Clement modifies the wording of quotations at least in a handful of cases.

${ }^{56}$ Lindemann, Die Clemensbriefe, 127 similarly comments on the convergence between the substitutions and Clement's intention.

57 'By presenting the rejection of the authority of the deposed leaders as a rejection of divinely established community structures, Clement made those structures explicit and by showing how the group's beliefs committed them to support for the leaders, he strengthened the normative character of those structures.' Maier, Social Setting of the Ministry, 119. ${ }^{58}$ Irenaeus also cites Isa 60:17 in connection with presbyters, but accurately according to the Septuagint (Adversus haereses 4 fragment 13). This shows Clement could likewise have made his point with the Septuagint's wording, but the modified wording makes it clearer and more straightforward.

${ }^{59}$ See M. Letteney, 'Authenticity and Authority: The Case for Dismantling a Dubious Correlation', Rethinking 'Authority in Late Antiquity: Authorship, Law, and Transmission in Jewish and Christian Tradition (ed. A. J. Berkovitz and M. Letteney; London: Routledge, 2018) 33-56. Letteney suggests that textual authority and authenticity need to be decoupled and offers fascinating examples from late antiquity: a text may be considered authentic and authored by an important figure (in Letteney's example Jesus!) and still lack authority.
} 
forgery: 'in some ancient cultures, the way to continue or return to the founder's discourse was precisely to ascribe what one said or wrote, not to oneself, but rather to the founder' ${ }^{60}$

In early Christian writings, pseudonymous attribution bloomed. Just as late Second Temple writers draw from Moses' or Solomon's authority, early Christians connected their writings with the apostles and comparable figures. Attributing a writing to Paul, Peter or James was a strong authority-conferring strategy, although the attribution alone did not suffice to make a text circulated, read and later approved by bishops. Although 1 Clement contains no pseudonymous attribution, the reception history of the letter can still highlight the relationship between textual authority and the author.

Despite the absence of an authoritative author in the letter itself, 1 Clement became highly valued - to the extent that Codex Alexandrinus ( $5^{\text {th }}$ century) included it just after Revelation. ${ }^{61}$ The author of the letter was soon identified as Clemens, the third bishop of Rome, ${ }^{62}$ and this episcopal identification provided the letter with a respectable and important author. Clement's person was an object of increasing interest in the third century, and previous accounts of his apostolic contacts were elaborated on. Origen even identified him as Paul's co-worker (cf. Phil 4:3). ${ }^{63}$ Several other writings were also connected with Clement's name, although from a historical-critical point of view it is clear that they have nothing to do with the author of 1 Clement. ${ }^{64}$ The respect and acknowledgment that 1 Clement enjoyed meant that the name of Clement commanded authority, and attributing other works to him was a strategy for partaking in that authority. In the end, the quality of 1 Clement's teaching and Clement's good name did not, however, suffice to include the letter in the most authoritative canons. ${ }^{65}$

\section{Conclusions}

I have argued that the authority of the Jewish writings and the authority of 1 Clement should be viewed in terms of mutual authorisation. 1 Clement builds important parts of the argument on retold narratives and scriptural quotations while simultaneously enhancing the authority of his source texts by proving their relevance and meaningfulness for his audience. The concept of mutual authorisation does not imply that the authoritativeness of the Jewish scriptures and 1 Clement would be enhanced in the same manner. 1 Clement strives to gain authority by interpreting sacred

\footnotetext{
${ }^{60}$ H. Najman, Seconding Sinai: The Development of Mosaic Discourse in Second Temple Judaism (Supplements to the Journal for the Study of Judaism 77; Leiden: Brill, 2003) 12; see further 9-17. As for the reception of a pseudonymous work, see Najman, 'Interpretation as Primordial Writing', 66: 'We cannot assume that Second Temple readers of Jubilees, such as the author(s) of the Damascus Document who cite(s) Jubilees as Scripture, took Moses' transcription of Jubilees to be an historical fact, because we cannot assume that they shared the relevant conception of history.'

${ }^{61}$ Including 1 Clement in Codex Alexandrinus highlights an important theme that cannot be discussed in this article, namely authority and manuscripts. Brooke calls attention to the varying degrees of authority assigned to individual copies; see Brooke, 'Authority and the Authoritativeness', 520-1. In the case of Codex Alexandrinus, the inclusion of 1 and 2 Clement in the fine codex reflects the high status of these writings.

${ }^{62}$ See Irenaeus Adversus haereses 3.3 for the succession. According to Irenaeus, Clement even met Paul and Peter in Rome. While Irenaeus does not directly say that Clement wrote the letter, he clearly connects Clement's time as the bishop with the sending of the letter.

${ }^{63}$ Origen, Commentarii in evangelium Ioannis 6.279, on Joh 1:29 (Sources chrétiennes 157, p. 340). For further primary texts and discussion, see Lona, Clemensbrief, 67.

${ }^{64}$ In the manuscript tradition, 1 Clement and the so-called 2 Clement are linked. For the Pseudo-Clementine Homilies (or Klementia) and Recognitions that recount Clement's life, adventures and travels with Peter, see F. S. Jones, 'Introduction to the Pseudo-Clementines', Pseudoclementina Elchasaiticaque inter Judaeochristiana; OLA 203; Leuven: Peeters, 2012) 7-49.

${ }^{65}$ Didymus the Blind and the Syriac work the Apostolic Canons (both from the second half of the $4^{\text {th }}$ century) seem to view 1 Clement as authoritative scripture (B. M. Metzger, The Canon of the New Testament: Its Origin, Development, and Significance (Oxford: Clarendon, 1987) 214; see also p. 222; A. Gregory, '1 Clement: An Introduction', ExpTim 117 (2006) 223-30, at 224).
} 
and ancestral writings, whereas the authority of the source material is strengthened through this actualizing interpretation (part of which is that Clement explicitly calls the scriptures sacred).

The authoritativeness of the Jewish scriptures in their Greek form is taken for granted and is never explicitly argued for in the letter. Yet it appears that this authority rests primarily on the oracular nature of the scriptures and on their divine mediation: they contain utterances from God, Christ and the Holy Spirit, and they are mediated by the Spirit. This is also the basis for calling the scriptures sacred. In addition to divine oracular authority, 1 Clement assumes an ancestral connection between the scriptures and his audience. The Romans and Corinthians appear as the direct heirs of the patriarchs: the scriptural narratives are their own ancestral tradition that is immediately relevant to their identity. That the audience can recognise this tradition as their own necessitates teaching and instruction. I suggest that $1 \mathrm{Clement}$ has instructional aims that are directly related to the dynamics of mutual authorisation. If the only objective of the letter had been to neatly settle the Corinthian crisis, surely a letter with a more focused argumentation would have been more suitable than the overlong and meandering 1 Clement with its extensive quotations. It appears to me probable that the aim of the letter was from the very beginning more ambitious: to become a letter that would provide material for the self-understanding of Christians and that would be widely circulated, read and studied. Finally, it appears that the immutability of the scriptures is not an important factor for their authoritativeness. For Clement, preserving the exact wording is a secondary factor, highlighting the immediate relevance being the primary concern.

Rather than offering a comprehensive list of strategies that 1 Clement uses to project authority, this article has viewed only those that are connected to its use of the Jewish scriptures and to the Corinthian conflict concerning leadership. The letter draws from the authority of the scriptures not only in its exhortation concerning humility, staying in one's divinely ordered position, meekness, and love of one's community, but also in a more straightforward manner. The scriptures offer a prooftext for the argument that the office of a bishop is divinely established and that the authority of the office holders comes from God through Christ and the apostles. The authority of a scriptural text, framed and interpreted by Clement, is thus immediately connected to struggles of power, influence and leadership. The scriptures have transformative potential in 1 Clement: they are to lead the rebels and the factious congregation to $\mu \varepsilon \tau \dot{\alpha} \nu_{\nu}$ i $\alpha$ and to the restoration of the divinely appointed bishops. Finally, through the scriptural argumentation, the senders of the letter appear as highly competent interpreters and teachers of authoritative tradition, which adds to the rhetorical force of the letter.

I hope to have shown that different aspects and construals of the authority of the scriptures, the authority of their interpreters, the identity-building of the early Christians, and questions concerning authorised leadership and power are deeply interrelated in the argumentation of the letter. 